\title{
Maternal Nutrition Status and Its Relation with Low Birth Weight: A Meta Analysis Study
}

\author{
Titik Wijayanti, Atik Setyaningsih, Wahyuningsih
}

Institute of Health Science Utomo, Boyolali, Central Java, Indonesia

\section{ABSTRACT}

Background: The condition of low birth weight (LBW) increases the risk of death in newborns early in life and results in health and development problems later in life. However, research related to factors associated with low birth weight is still limited. This study aimed to determine the risk factors associated with the nutritional status of mothers with low birth weight babies.

Subjects and Method: This was a systematic review and meta-analysis by searching for articles published by the online database PubMed in 2016 to 2021. With P: Pregnant women, I: height $<150 \mathrm{~cm}$, maternal mid-upper arm circumference (MUAC) $<23 \mathrm{~cm}$, did not receive nutrition counseling, C: height $>150 \mathrm{~cm}$, maternal MUAC $>23 \mathrm{~cm}$, receiving nutritional counseling, O: LBW. And the inclusion criteria of this study are: 1) articles that explain the influence of maternal nutritional status with LBW; 2) original research papers; 3) the research subjects were pregnant women who gave birth to LBW; 4) research using multivariate logistic regression analysis method. The dependent variable is low birth weight. The independent variable is a risk factor related to the nutritional status of the mother as measured by height, arm circumference, and the provision of nutritional counseling. Data analysis using RevMan software.

Results: There are 18 articles on quantitative analysis. Pregnant women who have a height $<150$ $\mathrm{cm}(\mathrm{OR}=3.13 ; 95 \% \mathrm{CI}=0.75$ to $13.10 ; \mathrm{p}=0.120)$ and maternal $\mathrm{MUAC}<23 \mathrm{~cm}(\mathrm{OR}=3.79 ; 95 \% \mathrm{CI}=$ 3.00 to $4.78 ; \mathrm{p}=0.001$ ) had a greater risk of giving birth to a baby with low birth weight. Likewise, pregnant women who did not receive nutritional counseling had a greater risk of experiencing low birth weight $(\mathrm{OR}=2.98 ; 95 \% \mathrm{CI}=2.11$ to $4.22 ; \mathrm{p}=0.001)$.

Conclusion: Pregnant women who have a height $<150 \mathrm{~cm}, \mathrm{MUAC}<23 \mathrm{~cm}$, and do not receive nutritional counseling have a greater risk of giving birth to babies with low birth weight.

Keywords: low birth weight, nutritional status, maternal, neonatal.

\section{Correspondence:}

Titik Wijayanti. Institute of Health Science Estu Utomo Boyolali. Jl.Tentara Pelajar km 7, Mudal, Kec Boyolali, Central Java 58111. Email: titikeub.tw@gmail.com. Mobile: +62 815-1407-4626.

Cite this as:

Wijayanti T, Setyaningsih A, Wahyuningsih (2021). Risk Factors Related to Maternal Nutrition Status in The Event of Low Birth Weight: A Meta Analysis Study. J Epidemiol and Public Health. 06(04): 438-449. https://doi.org/10.26911/jepublichealth.2021.06.04.05.

\section{Journal of Epidemiology and Public Health is licensed under a Creative Commons} Attribution-NonCommercial-ShareAlike 4.o International License.

\section{BACKGROUND}

Low birth weight (LBW) is defined as a baby's weight at birth below 2500 grams. Infants born prematurely ( $<37$ weeks gestation) and intrauterine growth restriction (IUGR), are significant predictors of neonatal mortality and morbidity. It is estimated that 20.5 million (14.6\%) babies globally are born with LBW, mainly (>90\%) in low and middle-income countries, especially in South Asia and sub-Saharan Africa (Blencowe et al., 2019; Christian et al., 2019). al., 2013; Fall, 2013). Globally, it is estimated 
that $15 \%$ to $20 \%$ of all births are to LBW (Lopes et al., 2017; WHO., 2014).

LBW has a negative impact on child survival, causing $40 \%$ to $80 \%$ of neonatal deaths due to related complications, stunted growth, disability, neurological developmental deficits, and chronic long-term health-related diseases such as diabetes and cardiovascular disease (Abu-Saad and Fraser, 2003; Risnes et al., 2011).

LBW can lead to the possibility of developing chronic diseases such as hypertension, cardiovascular disease, type II diabetes, metabolic syndrome, ischemic heart disease, decreased lung capacity, behavioral disorders, impaired physical, cognitive, and psychological functions, and long-term financial burdens. Chronic lung disease is higher among newborns weighing <1500gm (Kayode et al., 2014; Walter et al., 2009).

In developed countries, the main cause of LBW is premature birth, while in developing countries, Intrauterine Growth Restriction (IUGR) is the main cause of LBW (Siza, 2008).

A cohort study showed that vomiting during the early trimester of pregnancy was associated with a higher risk of developing low birth weight. In developing countries, maternal age, illiteracy, follow-up antenatal care, body mass index and socioeconomic status are predictors of the occurrence of LBW. Antepartum haemorrhage, hypertensive disorders of pregnancy and primiparity were associated with the incidence of LBW in the Gambia study. In addition, LBW is associated with maternal anemia and malaria during pregnancy. An epidemiological study conducted in Ethiopia identified several risk factors for LBW. Education and employment status, maternal height and weight, hypertensive disorders during pregnancy, congenital abnormalities and indoor pollution from the type of fuel used for cooking are predictors of LBW (Adane et al., 2014; Demelash et al., 2015; Guyatt and Snow, 2004; Mahumud et al., 2017; Mekonen et al., 2015; Petry et al., 2018; Rahman et al., 2016; Zeleke et al., 2012).

In 2014, the World Health Organization (WHO) identified evidence-based interventions to prevent LBW. Section 3 of the new Sustainable Development Goals (SDGs) targets broader health topics related to newborn and child health. As the SDGs address a wide range of socio-economic and environmental risk factors for health-related problems, identifying risk factors for low birth weight has many benefits for establishing prevention and treatment strategies (WHO, 2014; WHO, 2016).

Based on this, the researcher feels the importance of conducting research that investigates several risk factors related to the nutritional status of the mother in the incidence of low birth weight babies.

\section{SUBJECTS AND METHOD}

\section{Study Design}

This was a systematic review and metaanalysis.

\section{Inclusion Criteria}

Search articles using the PubMed online database. The articles used in this review are articles published from 2016 to 2021. In the article search process, researchers used the keywords "low birth weight", "nutrional status", "maternal", and "neonatal". The inclusion criteria of this study were: 1 ) an article explaining the effect of maternal nutritional status with LBW; 2) original research papers; 3) the research subjects were pregnant women who gave birth to LBW; 4) research using multivariate logistic regression analysis method. The exclusion criteria for this study were: 1) articles in languages other than English and Indonesian; 2) review papers; 3) research data is incomplete or not available. 


\section{Study Variable}

The dependent variable was low newborn weight. The independent variable is a risk factor related to the nutritional status of the mother as measured by height, arm circumference, and the provision of nutritional counseling.

\section{Operational Definition of Variable}

Low newborn weight is a baby's weight after birth of less than 2500 grams. Height is the height of the mother who is less than $150 \mathrm{~cm}$, the arm circumference is the size of the arm circumference of the mother which is less than $23 \mathrm{~cm}$, and the provision of nutritional counseling is the provision of information about nutrition or balanced nutrition for pregnant women during pregnancy.

\section{Study Instrument}

Article searches were conducted using an online database (PubMed). The process of searching and filtering articles was carried out using a Prism diagram (chart 1). Articles included in this study must meet the inclusion criteria and have been reviewed using a critical appraisal in accordance with the research design of each article.

\section{RESULTS}

\section{Characteristics Subjects}

There are a total of 198 articles searched from the PubMed online database using the keywords "low birth weight", "nutrional status", "maternal", and "neonatal" by selecting the year of publication between 20162021. There were a total of 18 articles that met the inclusion criteria and were processed in qualitative and quantitative synthesis. The characteristics of each article included in the qualitative synthesis have been described in table 1. Extracted data for each article can be seen in table 2. The number of references and journal sources can be seen in table 3 . There are 3 risk fac- tors analyzed using the review manager application.

\section{Analysis of the Effect of Mother's Height with Low Birth Weight}

here are 5 articles that explain the effect of maternal height on the incidence of low birth weight. The results of the meta-analysis showed that mothers with a height of less than $150 \mathrm{~cm}$ had a 3.13 higher risk of low birth weight compared to mothers who had a height above or equal to $150 \mathrm{~cm}$, although statistically, this result was not significant.

\section{Analysis of the Effect of Mother's Arm Circumference with Low Birth Weight Incidents}

There are 8 articles that explain the effect of maternal arm circumference on the incidence of low birth weight babies. The results of the meta-analysis showed that mothers who had an arm circumference of less than $23 \mathrm{~cm}$ had a 3.79 higher risk of low birth weight compared to mothers who had an arm circumference above or equal to 23 $\mathrm{cm}$ and this result was statistically significant.

\section{Analysis of the Effect of Nutrition Counseling with Low Birth Weight Incidents}

There are 5 articles that explain the effect of providing nutritional counseling to mothers with low birth weight babies. The results of the meta-analysis showed that mothers who didn't receive nutrition counseling had a 2.98 higher risk of developing low birth weight compared to mothers who received nutrition counseling, this result was statistically significant. 
Wijayanti et al./ Maternal Nutrition Status and Its Relation with Low Birth Weight

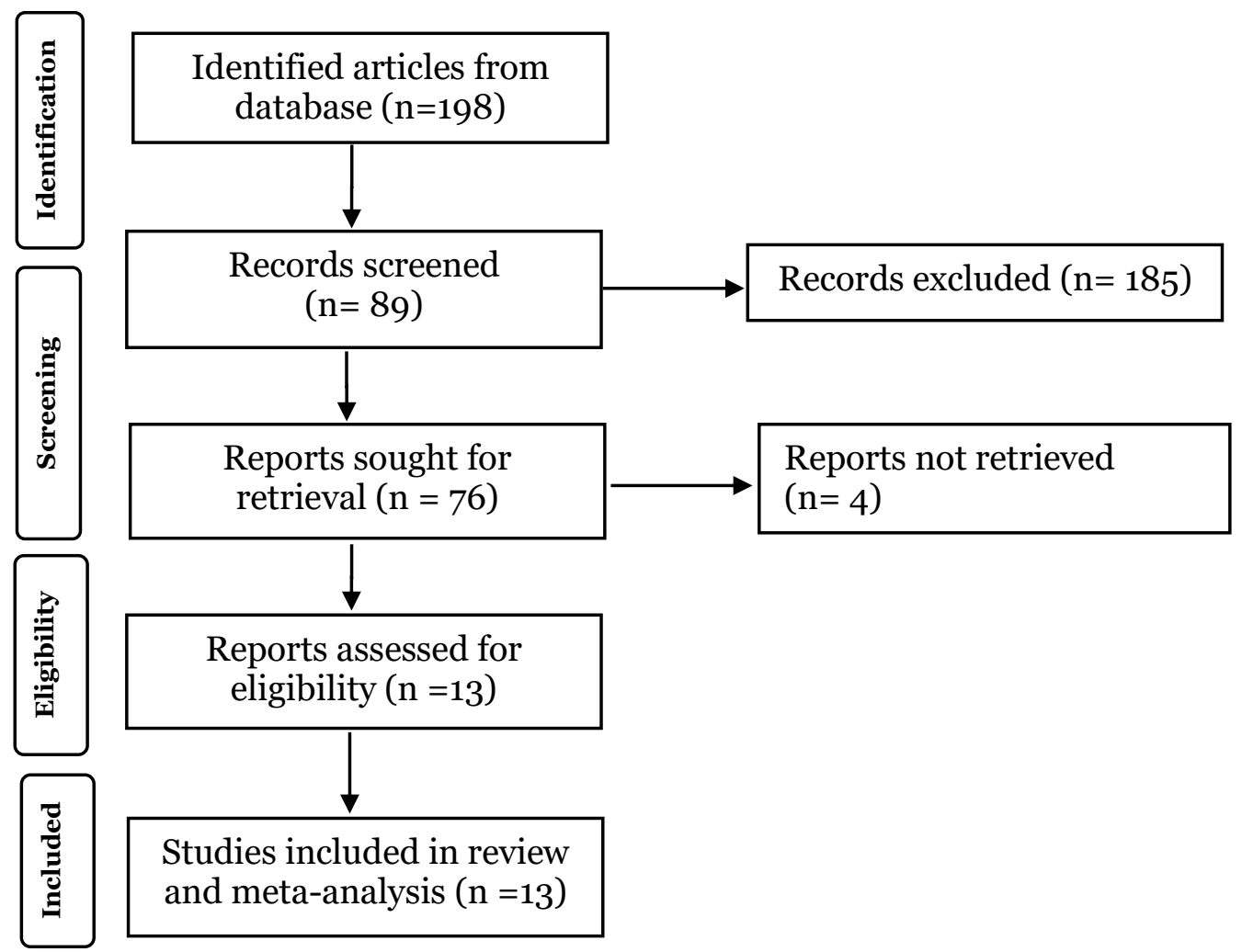

Figure 1. PRISMA Diagram

Table 2. Extraction of data based on references included in quantitative analysis

\begin{tabular}{llccc}
\hline \multicolumn{1}{c}{ Variable } & \multicolumn{1}{c}{ Study (Year) } & aOR & 95\% CI & Total of Sample \\
\hline Maternal & Sema et al. (2019) & 3.54 & 1.07 to 11.76 & 431 \\
height & Bater et al. (2020) & O.42 & 0.24 to 0.72 & 5,152 \\
$<\mathbf{1 5 0} \mathbf{~ c m}$ & Desta et al. (2020) & 9.27 & 3.45 to 24.89 & 381 \\
$\geq 150 \mathrm{~cm}$ & Aboye et al. (2018) & 4.61 & 1.34 to 15.8 & 308 \\
& Mulu et al. (2020) & 5.70 & 1.70 to 19.70 & 279 \\
Arm & Abera et al. (2019) & 6.51 & 2.85 to 14.91 & 380 \\
circumference & Girma et al. (2019) & 5.62 & 2.64 to 11.97 & 279 \\
$<23 \mathrm{~cm}$ & Ahmed et al. (2018) & 5.62 & 2.64 to 11.97 & 286 \\
$\geq 23 \mathrm{~cm}$ & Siyoun and Melese (2019) & 2.90 & 1.47 to 5.81 & 330 \\
& Bekela et al. (2020) & 4.27 & 2.24 to 8.50 & 354 \\
& Beyene et al. (2021) & 2.39 & 1.60 to 3.59 & 970 \\
& Adane and Dachew (2018) & 3.40 & 1.38 to 8.60 & 662 \\
Nutrition & Mingude et al. (2020) & 7.99 & 3.50 to 20.30 & 300 \\
counselling & Sema et al. (2019) & 2.03 & 1.01 to 4.06 & 431 \\
Yes & Girma et al. (2019) & 4.05 & 1.95 to 8.38 & 279 \\
No & Ahmed et al. (2018) & 4.05 & 1.15 to 7.03 & 286 \\
& Siyoum and Melese (2019) & 2.37 & 1.30 to 4.34 & 330 \\
\hline
\end{tabular}


Table 1. Summary of Characteristics in Each Article

\begin{tabular}{|c|c|c|c|}
\hline $\begin{array}{l}\text { Author } \\
\text { (year) }\end{array}$ & Title & $\begin{array}{l}\text { Study } \\
\text { Design }\end{array}$ & Results \\
\hline $\begin{array}{l}\text { Sema et al. } \\
\text { (2019) }\end{array}$ & $\begin{array}{l}\text { Associated Factors with Low Birth Weight in Dire Dawa City, } \\
\text { Eastern Ethiopia: A Cross-Sectional Study }\end{array}$ & $\begin{array}{l}\text { A Cross- } \\
\text { Sectional }\end{array}$ & $\begin{array}{l}\text { Factors that influence the incidence of LBW are maternal height } \\
\text { and arm circumference. }\end{array}$ \\
\hline $\begin{array}{l}\text { Abera et al. } \\
\text { (2019) }\end{array}$ & $\begin{array}{l}\text { Nutritional and non-nutritional factors associated with low birth } \\
\text { weight in Sawula Town, Gamo Gofa Zone, Southern Ethiopia }\end{array}$ & $\begin{array}{l}\text { A Cross- } \\
\text { Sectional }\end{array}$ & $\begin{array}{l}\text { Factors that influence the incidence of LBW is maternal arm } \\
\text { circumference. }\end{array}$ \\
\hline $\begin{array}{l}\text { Aboye et al. } \\
\text { (2018) }\end{array}$ & $\begin{array}{l}\text { Prevalence and associated factors of low birth weight in Axum } \\
\text { town, Tigray, North Ethiopia }\end{array}$ & $\begin{array}{l}\text { A Cross- } \\
\text { Sectional }\end{array}$ & $\begin{array}{l}\text { Mothers who have a height of more than } 150 \mathrm{~cm} \text { have a greater risk } \\
\text { of giving birth to LBW. }\end{array}$ \\
\hline $\begin{array}{l}\text { Adane and } \\
\text { Dachew } \\
(2018)\end{array}$ & $\begin{array}{l}\text { Low birth weight and associated factors among singleton neonates } \\
\text { born at Felege Hiwot referral hospital, North West Ethiopia }\end{array}$ & $\begin{array}{l}\text { A Cross- } \\
\text { Sectional }\end{array}$ & $\begin{array}{l}\text { Pregnant women who have arm circumference }<23 \mathrm{~cm} \text { are at } \\
\text { greater risk of giving birth to LBW. }\end{array}$ \\
\hline $\begin{array}{l}\text { Bater et al. } \\
(2020)\end{array}$ & $\begin{array}{l}\text { Predictors of low birth weight and preterm birth in rural Uganda: } \\
\text { Findings from a birth cohort study }\end{array}$ & Cohort & $\begin{array}{l}\text { Mothers who have a height of more than } 150 \mathrm{~cm} \text { have a lower risk of } \\
\text { giving birth to LBW. }\end{array}$ \\
\hline $\begin{array}{l}\text { Beyene et } \\
\text { al. (2021) }\end{array}$ & $\begin{array}{l}\text { The effect of antenatal depression on birth weight among } \\
\text { newborns in South Gondar zone, Northwest Ethiopia: a } \\
\text { population-based prospective cohort study }\end{array}$ & Cohort & $\begin{array}{l}\text { Factors that influence the incidence of LBW are maternal height } \\
\text { and arm circumference. }\end{array}$ \\
\hline $\begin{array}{l}\text { Girma et al. } \\
(2019)\end{array}$ & $\begin{array}{l}\text { Factors associated with low birthweight among newborns } \\
\text { delivered at public health facilities of Nekemte town, West } \\
\text { Ethiopia: a case control study }\end{array}$ & $\begin{array}{l}\text { Case- } \\
\text { control }\end{array}$ & $\begin{array}{l}\text { The provision of nutritional counseling and the size of the arm } \\
\text { circumference were associated with the incidence of LBW. }\end{array}$ \\
\hline $\begin{array}{l}\text { Mulu et al. } \\
(2020)\end{array}$ & $\begin{array}{l}\text { Determinants of Low Birth Weight Among Newborns Delivered in } \\
\text { Public Hospitals in Addis Ababa, Ethiopia: Case-Control Study }\end{array}$ & $\begin{array}{l}\text { Case- } \\
\text { control }\end{array}$ & $\begin{array}{l}\text { Mothers who have a height of more than } 150 \mathrm{~cm} \text { have a lower risk of } \\
\text { giving birth to LBW. }\end{array}$ \\
\hline $\begin{array}{l}\text { Ahmed et } \\
\text { al. (2018) }\end{array}$ & $\begin{array}{l}\text { A health facility based case-control study on determinants of low } \\
\text { birth weight in Dassie town, Northeast Ethiopia: the role of } \\
\text { nutritional factors }\end{array}$ & $\begin{array}{l}\text { Case- } \\
\text { control }\end{array}$ & $\begin{array}{l}\text { Pregnant women who do not receive nutrition counseling have a } \\
\text { risk of giving birth to low birth weight. }\end{array}$ \\
\hline $\begin{array}{l}\text { Siyoum and } \\
\text { Melese } \\
\text { (2019) }\end{array}$ & $\begin{array}{l}\text { Factors associated with low birth weight among babies born at } \\
\text { Hawassa University Comprehensive Specialized Hospital, } \\
\text { Hawassa, Ethiopia }\end{array}$ & $\begin{array}{l}\text { Case- } \\
\text { control }\end{array}$ & $\begin{array}{l}\text { Pregnant women who do not receive nutrition counseling, and } \\
\text { whose arm circumference is less than } 22 \mathrm{~cm} \text { are at risk of giving } \\
\text { birth to low birth weight. }\end{array}$ \\
\hline $\begin{array}{l}\text { Bekela et al. } \\
(2020)\end{array}$ & $\begin{array}{l}\text { Determinants of Low Birth Weight among Newborns Delivered at } \\
\text { Public Hospitals in Sidama Zone, South Ethiopia: Unmatched } \\
\text { Case-Control Study }\end{array}$ & $\begin{array}{l}\text { Case- } \\
\text { control }\end{array}$ & $\begin{array}{l}\text { Pregnant women who have an arm circumference of less than } 22 \mathrm{~cm} \\
\text { are at risk of giving birth to LBW. }\end{array}$ \\
\hline $\begin{array}{l}\text { Desta et al. } \\
(2020)\end{array}$ & $\begin{array}{l}\text { Maternal factors associated with low birth weight in public } \\
\text { hospitals of Mekelle city, Ethiopia: a case-control study }\end{array}$ & $\begin{array}{l}\text { Case- } \\
\text { control }\end{array}$ & $\begin{array}{l}\text { Mothers with a height of less than } 150 \mathrm{~cm} \text { have a risk of giving birth } \\
\text { to LBW. }\end{array}$ \\
\hline $\begin{array}{l}\text { Mingude et } \\
\text { al. (2020) }\end{array}$ & $\begin{array}{l}\text { Determinants of low birth weight among live birth newborns } \\
\text { delivered at public hospitals in Gamo Gofa Zone, South Ethiopia: } \\
\text { Unmatched case control study }\end{array}$ & $\begin{array}{l}\text { Case- } \\
\text { control }\end{array}$ & $\begin{array}{l}\text { The provision of nutritional counseling and the size of the arm } \\
\text { circumference were associated with the incidence of LBW. }\end{array}$ \\
\hline
\end{tabular}


Wijayanti et al./ Maternal Nutrition Status and Its Relation with Low Birth Weight

Table 3. Number of references and journal sources

\begin{tabular}{lc}
\hline \multicolumn{1}{c}{ Journal Source } & Number of References \\
\hline BioMed Research International & 1 \\
BMC Pregnancy Childbirth & 1 \\
BMC Research Notes & 1 \\
International Journal of Pediatrics & 1 \\
Journal of pregnancy & 1 \\
Archives of public health & 1 \\
Italian journal of pediatrics & 3 \\
Journal of Nepal Health Research Council & 1 \\
PloS one & 1 \\
SAGE open medicine & 1 \\
BMC research notes & 2 \\
Pediatric health, medicine and therapeutics & 1 \\
\hline
\end{tabular}

The characteristics of each article included in the qualitative synthesis are described in table 1 . The articles included in this systematic review and meta-analysis study are research articles using cross-sectional research methods. Subjects included in this study were infants weighing $<2500$ grams and infants weighing 2500 grams as controls. All studies included in this research analysis are located in the country of Ethiopia.

\section{Effect of Maternal Anemia on the Incidence of $\mathbf{L B W}$}

The results of pooled odds ratio analysis showed that pregnant women who were anemic during pregnancy had an odds of
3.42 being more prone to giving birth to LBW babies compared to mothers who did not experience anemia, this result was statistically significant $(\mathrm{p}<0.001)$. The heterogeneity value $\left(\mathrm{I}^{2}\right)$ showed the number $62 \%$ $(\mathrm{p}=0.006)$, so the results of this meta-analysis used random effects (Figure 2).

Based on the funnel plot of the metaanalysis of the relationship between anemia in pregnant women and the incidence of LBW babies, there is a publication bias which is indicated by the asymmetry of the study by looking at the number of dots on the right and left sides and comparing it with the standard error (Figure 3).

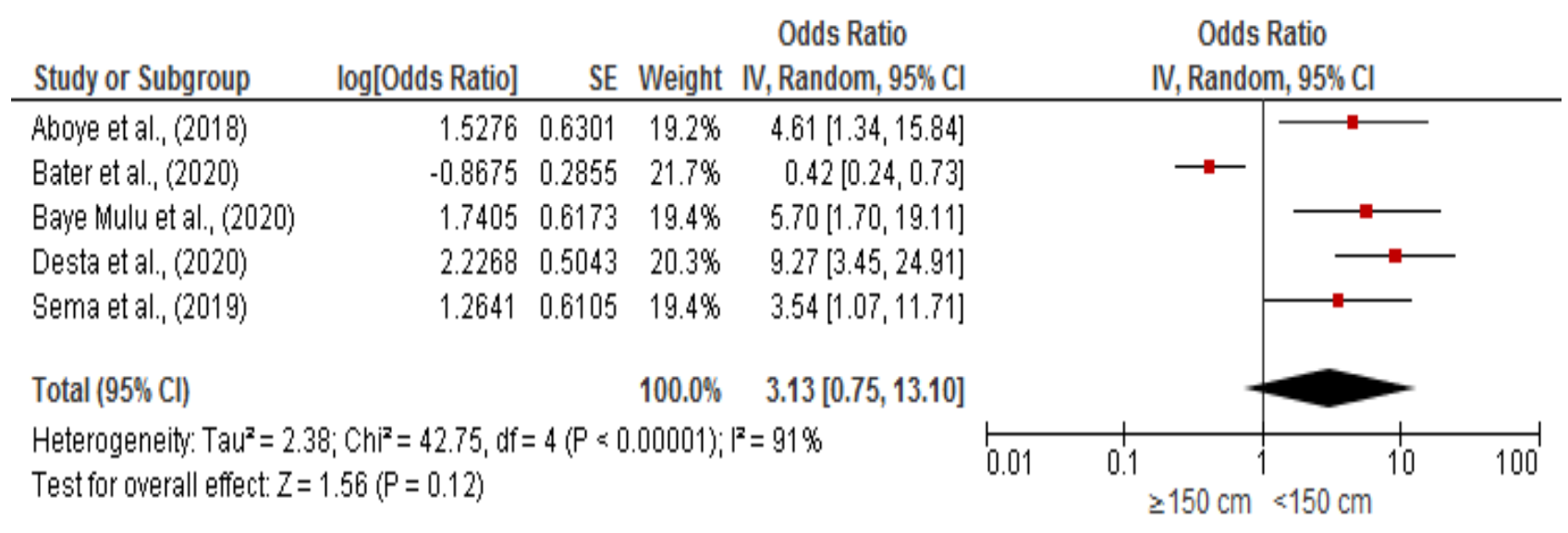

Figure 2. Forest plot of mother's height variable 
Wijayanti et al./ Maternal Nutrition Status and Its Relation with Low Birth Weight

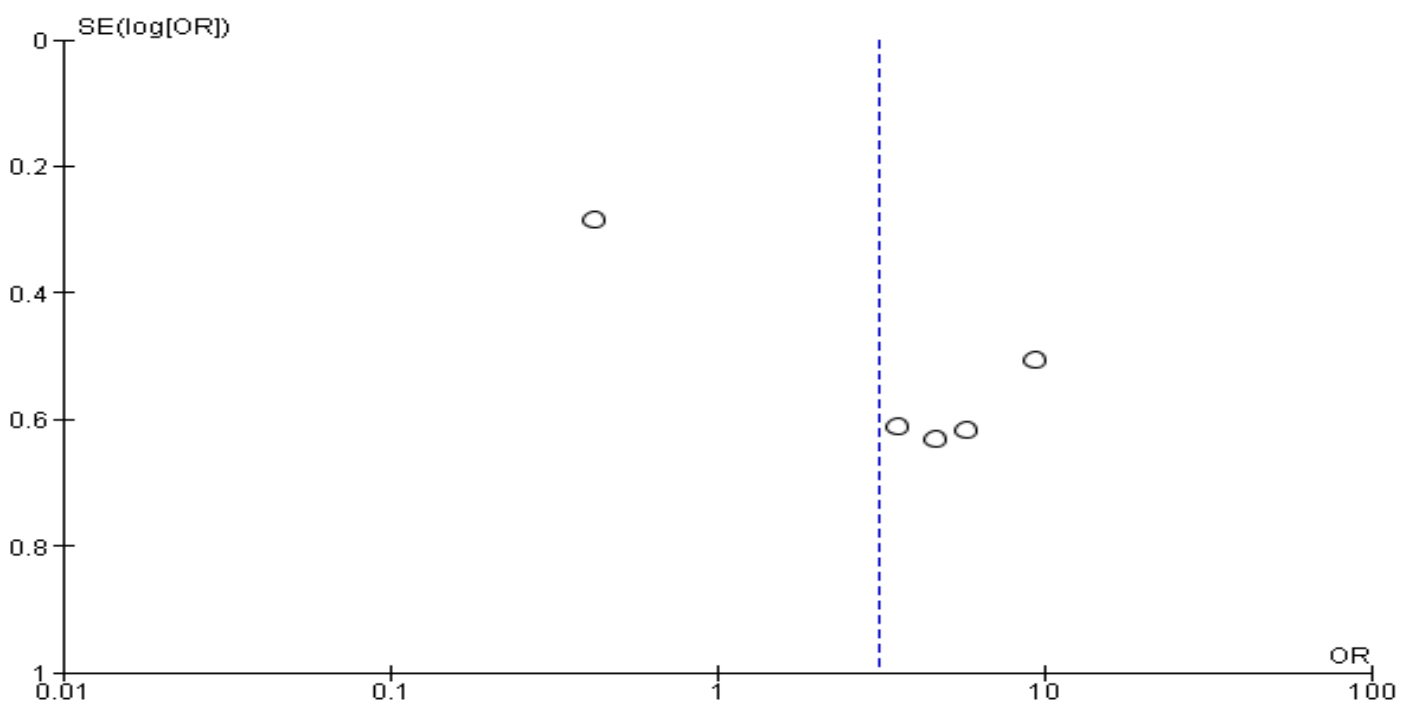

Figure 3. Funnel plot of mother's height variable

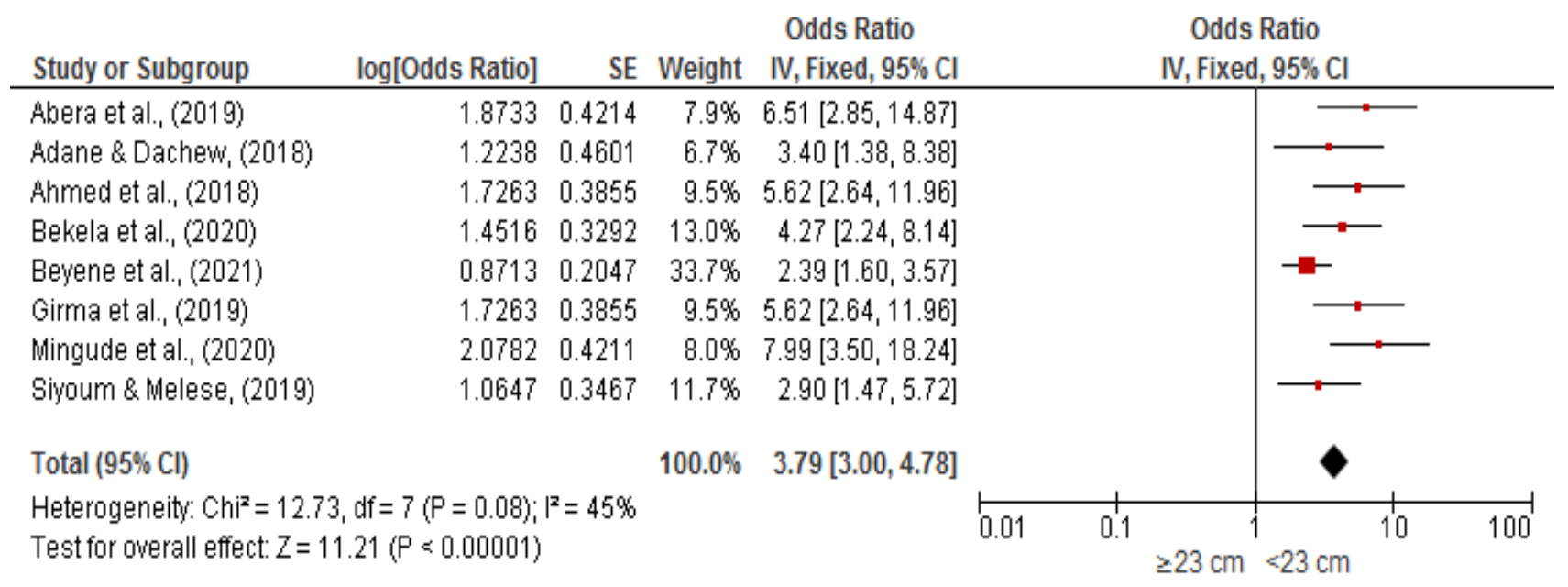

Figure 4. Forest plot of maternal arm circumference variable

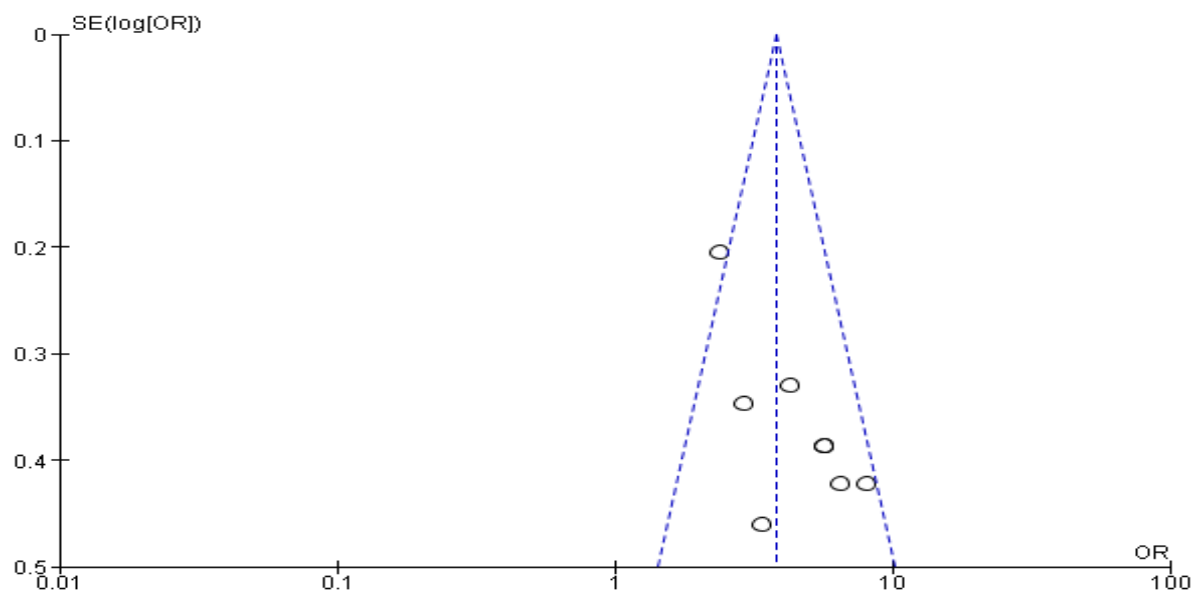

Figure 5. Funnel plot of maternal arm circumference 


\begin{tabular}{|c|c|c|c|c|c|c|c|c|}
\hline Study or Subgroup & log[Odds Ratio] & SE & Weight & $\begin{array}{l}\text { Odds Ratio } \\
\text { IV, Fixed, } 95 \% \mathrm{Cl}\end{array}$ & \multicolumn{4}{|c|}{$\begin{array}{c}\text { Odds Ratio } \\
\text { IV, Fixed, } 95 \% \mathrm{Cl}\end{array}$} \\
\hline Ahmed et al., (2018) & 1.3987 & 0.6423 & $7.6 \%$ & $4.05[1.15,14.26]$ & & & & \\
\hline Girma et al., (2019) & 1.3987 & 0.3729 & $22.5 \%$ & $4.05[1.95,8.41]$ & & & & \\
\hline Mingude et al., (2020) & 1.7664 & 0.5131 & $11.9 \%$ & $5.85[2.14,15.99]$ & & & & \\
\hline Sema et al., (2019) & 0.708 & 0.3562 & $24.7 \%$ & $2.03[1.01,4.08]$ & & & $\longrightarrow$ & \\
\hline Siyoum \& Melese, (2019) & 0.8629 & 0.3064 & $33.3 \%$ & $2.37[1.30,4.32]$ & & & $\rightarrow-$ & \\
\hline Total $(95 \% \mathrm{Cl})$ & & & $100.0 \%$ & $2.98[2.11,4.22]$ & & & & \\
\hline \multicolumn{3}{|c|}{$\begin{array}{l}\text { Heterogeneity: } \mathrm{Chi}^{2}=4.35, \mathrm{df}=4(P=0.36) ;\left.\right|^{2}=8 \% \\
\text { Test for overall effect: } Z=6.18(P<0.00001)\end{array}$} & & & 0.01 & 0.1 & No & 100 \\
\hline
\end{tabular}

Figure 6. Forest plot of nutrition counseling variables

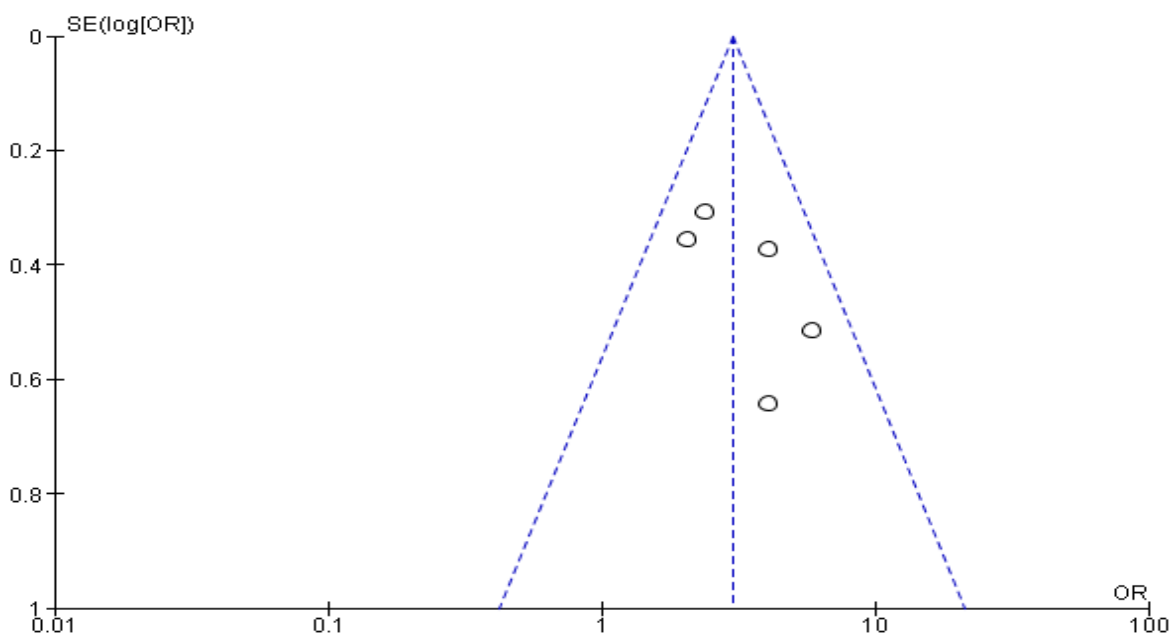

Figure 7. Funnel plot of nutrition counseling variables

\section{DISCUSSION}

Pregnant women who are less than $<150$ $\mathrm{cm}$ tall have a greater risk of giving birth to babies with low birth weight $(\mathrm{OR}=3.13)$, this is in accordance with research conducted by Demelash et al., 2015; Inoue et al., 2016; Zhang et al., 2015 who explained that pregnant women with a height of less than $150 \mathrm{~cm}$ had a higher risk of giving birth to low birth weight compared to pregnant women with a height of $150 \mathrm{~cm}$ or more.

The relationship between maternal height and fetal growth measures (i.e., birth length and birth weight) is determined by fetal genetics but not by nongenetic intrauterine effects (i.e., maternal height as an environmental factor that indirectly affects fetal growth) (Zhang et al., 2015).

Pregnant women who have arm circumferences $<23 \mathrm{~cm}$ have a greater risk of giving birth to babies with low birth weight $(\mathrm{OR}=3.79)$. Assefa et al. (2012) and Ververs et al. (2013) reported that pregnant women with MUAC less than $23.5 \mathrm{~cm}$ are at risk of giving birth to babies with low birth weight compared to pregnant women with normal MUAC.

Arm circumference is a good indicator because it is part of the body's protein reserves, and thin arms reflect a state of lean body mass, such as malnutrition. Arm circumference was identified as an indicator of 
choice to determine the nutritional status of pregnant women because of its relatively strong relationship with LBW, narrow range of values, simplicity of measurement and does not require prior knowledge of gestational age (Ververs et al., 2013).

Pregnant women who do not receive nutritional counseling have a greater risk of experiencing low birth weight $(\mathrm{OR}=2.98)$, this is in accordance with Baghianimoghadam et al. (2015); Talie et al. (2019), and Zeleke et al. (2012) who received nutritional counseling or balanced nutrition for pregnant women during pregnancy had a lower risk of giving birth to LBW babies compared to pregnant women who did not receive balanced nutrition counseling.

Mothers who did not receive nutritional counseling during antenatal care (ANC) were more likely to give birth to LBW babies compared to mothers who received nutritional counseling during ANC follow-up. This is a fact that counseling about nutrition has increased awareness of pregnant women about nutrition during pregnancy so that pregnant women can increase their nutritional intake to become balanced nutrition during pregnancy (Zeleke et al., 2012).

The conclusion of this study is that pregnant women who have a height less than $<150 \mathrm{~cm}$, arm circumference less than $<23 \mathrm{~cm}$, and do not receive nutritional counseling have a greater risk of giving birth to babies with low birth weight.

\section{AUTHOR CONTRIBUTION}

Titik Wijayanti and Atik Setyaningsih as analysis, and Wahyuningsih as article writer.

\section{FUNDING AND SPONSORSHIP}

This study is self-funded.

\section{CONFLICT OF INTEREST}

There is no conflict of interest in this study.

\section{ACKNOWLEDGMENT}

Thanks to the online database provider PubMed.

\section{REFERENCES}

Abera Z, Ejara D, Gebremedhin S (2019). Nutritional and non-nutritional factors associated with low birth weight in Sawula Town, Gamo Gofa Zone, Southern Ethiopia. BMC Res Notes. 12(1): 540. DOI: 10.1186/s13104-0194529-0.

Aboye W, Berhe T, Birhane T, Gerensea H (2018). Prevalence and associated factors of low birth weight in Axum town, Tigray, North Ethiopia. BMC Res Notes. 11(1): 684. DOI: 10.1186/s13104-018-3801-z.

Abu-Saad K, Fraser D (2010). Maternal nutrition and birth outcomes. Epidemiol. Rev. 32: 5-25. DOI: 10.1093/epirev/mxqoo1.

Adane AA, Ayele TA, Ararsa LG, Bitew BD, Zeleke BM (2014). Adverse birth outcomes among deliveries at Gondar University Hospital, Northwest Ethiopia. BMC Pregnancy Childbirth. 14: 90. DOI: 10.1186/1471-2393-14-90.

Adane T, Dachew BA (2018). Low birth weight and associated factors among singleton neonates born at Felege Hiwot referral hospital, North West Ethiopia. Afr. Health Sci. 18(4): 12041213. DOI: 10.4314/ahs.v18i4.42.

Ahmed S, Hassen K, Wakayo T (2018). A health facility based case-control study on determinants of low birth weight in Dassie town, Northeast Ethiopia. the role of nutritional factors. Nutr J. 17(1): 103. DOI: 10.1186/s12937-018-0409-Z

Assefa N, Berhane Y, Worku A (2012). 
Wijayanti et al./ Maternal Nutrition Status and Its Relation with Low Birth Weight

Wealth status, mid upper arm circumference (MUAC) and antenatal care (ANC) are determinants for low birth weight in Kersa, Ethiopia. PloS One. 7(6): e39957. DOI: 10.1371/journal.pone.0039957.

Baghianimoghadam $\mathrm{MH}$, Baghianimoghadam B, Ardian N, Alizadeh E (2015). Risk factors of low birth weight and effect of them on growth pattern of children up to sixth months of life: A cross-sectional study. J. Educ. Health Promot. 4: 40. DOI: 10.4103/22779531.157226.

Bater J, Lauer JM, Ghosh S, Webb P, Agaba E, Bashaasha B, Turyashemererwa FM, Shrestha R, Duggan CP (2020). Predictors of low birth weight and preterm birth in rural Uganda, Findings from a birth cohort study. PloS One. 15 (7): eo235626-eo235626. DOI: 10.1371/journal.pone.0235626.

Bekela MB, Shimbre MS, Gebabo TF, Geta MB, Tonga AT, Zeleke EA, Sidemo $\mathrm{NB}$, et al. (2020). Determinants of Low Birth Weight among Newborns Delivered at Public Hospitals in Sidama Zone, South Ethiopia, Unmatched Case-Control Study. J Pregnancy. 4675701. DOI: 10.1155/2020/4675701.

Beyene GM, Azale T, Gelaye KA, Ayele TA (2021). The effect of antenatal depression on birth weight among newborns in South Gondar zone, Northwest Ethiopia, a population-based prospective cohort study. Arch Public Health. 79(1): 121. DOI: 10.1186/s13690-021-00643-y.

Blencowe H, Krasevec J, de Onis M, Black RE, An X, Stevens GA, Borghi E, et al. (2019). National, regional, and worldwide estimates of low birthweight in 2015, with trends from 2000: a systematic analysis. The Lancet. Global
Health, Notes. 7(7): e849-e86o. DOI: 10.1016/S2214-109X(18)30565-5.

Christian P, Lee SE, Donahue Angel M, Adair LS, Arifeen S E, Ashorn P, Barros FC, et al. (2013). Risk of childhood undernutrition related to smallfor-gestational age and preterm birth in low- and middle-income countries. Int $\mathrm{J}$ Epidemiol. 42(5): 1340-1355. DOI: 10.1093/ije/dyt109.

da Silva Lopes K, Ota E, Shakya P, Dagvadorj A, Balogun O O, Peña-Rosas J P, De-Regil LM, Mori R (2017). Effects of nutrition interventions during pregnancy on low birth weight: an overview of systematic reviews. BMJ Glob. Health. 2(3): eooo389. DOI: 10.1136/bmjgh-2017-000389.

Demelash H, Motbainor A, Nigatu D, Gashaw K, Melese A (2015). Risk factors for low birth weight in Bale zone hospitals, South-East Ethiopia: a case-control study. BMC Pregnancy and Childbirth. 15: 264. DOI: 10.1186/s12884-015-0677-y.

Desta SA, Damte A, Hailu T (2020). Maternal factors associated with low birth weight in public hospitals of Mekelle city, Ethiopia: a case-control study. Ital J Pediatr. 46(1): 124. DOI: 10.1186/s13052-020-00890-9.

Fall CHD (2013). Fetal malnutrition and long-term outcomes. Nestle Nutr Inst Workshop Ser. 74: 11-25. DOI: 10.1159/000348384

Girma S, Fikadu T, Agdew E, Haftu D, Gedamu G, Dewana Z, Getachew B (2019). Factors associated with low birthweight among newborns delivered at public health facilities of $\mathrm{Ne}-$ kemte town, West Ethiopia: a case control study. BMC Pregnancy Childbirth Notes. 19(1): 220. DOI: 10.1186/s12884-019-2372-x.

Guyatt HL, Snow RW (2004). Impact of 
Wijayanti et al./ Maternal Nutrition Status and Its Relation with Low Birth Weight

malaria during pregnancy on low birth weight in sub-Saharan Africa. Clin Microbiol Rev. 17(4): 760-769, table of contents. DOI: $10.1128 / \mathrm{CMR}-$ .17.4.760-769.2004.

Inoue $\mathrm{S}$, Naruse $\mathrm{H}$, Yorifuji $\mathrm{T}$, Kato $\mathrm{T}$, Murakoshi T, Doi H, Subramanian SV (2016). Association between Short Maternal Height and Low Birth Weight: a Hospital-based Study in Japan. J Korean Med Sci. 31(3): 353359. DOI: $10.3346 / \mathrm{jkms.2016.31.3.3-}$ 53.

Kayode GA, Amoakoh-Coleman M, Agyepong IA, Ansah E, Grobbee, DE, Klipstein-Grobusch K (2014). Contextual risk factors for low birth weight: a multilevel analysis. PloS One. 9(10): e109333. DOI: 10.1371/journal.pone.0109333.

Mahumud RA, Sultana M, Sarker AR (2017). Distribution and Determinants of Low Birth Weight in Developing Countries. J Prev Med Public Health. 5O(1): 18-28. DOI: 10.3961/jpmph.16.087.

Mekonen HK, Nigatu B, Lamers WH (2015). Birth weight by gestational age and congenital malformations in Northern Ethiopia. BMC Pregnancy Childbirth. 15: 76. DOI: 10.1186/s12884-015-0507-2.

Mingude AB, Gebretsadik W, Misker D, Woldeamanuel GG (2020). Determinants of low birth weight among live birth newborns delivered at public hospitals in Gamo Gofa Zone, South Ethiopia: Unmatched case control study. SAGE Open Med. 8: 2050312120940544-2050312120940544.

DOI: 10.1177/2050312120940544.

Mulu GB, Gebremichael B, Wondwossen Desta K, Adimasu Kebede M, Asmare Aynalem Y, Bimirew Getahun M (2020). Determinants of Low Birth
Weight Among Newborns Delivered in Public Hospitals in Addis Ababa, Ethiopia: Case-Control Study. Pediatric Health Med Ther. 11: 119-126. DOI: 10.2147/PHMT.S246008.

Petry CJ, Ong KK, Beardsall K, Hughes IA, Acerini CL, Dunger DB (2018). Vomiting in pregnancy is associated with a higher risk of low birth weight: a cohort study. BMC Pregnancy Childbirth Notes. 18(1): 133. DOI: 10.1186/s12884-018-1786-1.

Rahman MM, Abe SK, Rahman MS, Kanda M, Narita S, Bilano V, Ota E, Gilmour S, Shibuya K (2016). Maternal anemia and risk of adverse birth and health outcomes in low and middle-income countries: systematic review and meta-analysis. Am J Clin Nutr. 103(2): 495-504. DOI: 10.3945/ajcn.115.107896.

Risnes KR, Vatten LJ, Baker JL, Jameson K, Sovio U, Kajantie E, Osler M, et al. (2011). Birthweight and mortality in adulthood: a systematic review and meta-analysis. Int J Epidemiol. 40(3): 647-661. DOI: 10.1093/ije/dyq267

Sema A, Tesfaye F, Belay Y, Amsalu B, Bekele D, Desalew A (2019). Associated Factors with Low Birth Weight in Dire Dawa City, Eastern Ethiopia: A Cross-Sectional Study. Biomed Res. Int. 2019: 2965094. DOI: 10.1155/2019/2965094.

Siyoum M, Melese T (2019). Factors associated with low birth weight among babies born at Hawassa University Comprehensive Specialized Hospital, Hawassa, Ethiopia. Ital $\mathrm{J}$ Pediatr. 45(1): 48. DOI: $10.1186 / \mathrm{s} 13052-019-$ 0637-7

Siza JE (2008). Risk factors associated with low birth weight of neonates among pregnant women attending a referral hospital in northern Tanzania. Tanzan 
Wijayanti et al./ Maternal Nutrition Status and Its Relation with Low Birth Weight

J Health Res. 10(1): 1-8. DOI: 10.4314/thrb.v10i1.14334

Talie A, Taddele M, Alemayehu M (2019). Magnitude of Low Birth Weight and Associated Factors among Newborns Delivered in Dangla Primary Hospital, Amhara Regional State, Northwest Ethiopia, 2017. J. Pregnancy. 2019: 3587239. DOI: $10.1155 / 2019 / 35872-$ 39.

Ververs M-T, Antierens A, Sackl A, Staderini N, Captier V (2013). Which anthropometric indicators identify a pregnant woman as acutely malnourished and predict adverse birth outcomes in the humanitarian context? PLoS Curr. 5. DOI: 10.1371/currents.dis.54a8b618c1bc031ea140e3f293459 $9 c 8$.

Walter EC, Ehlenbach WJ, Hotchkin DL, Chien JW, Koepsell TD (2009). Low birth weight and respiratory disease in adulthood: a population-based case-control study. Am J Respir Crit Care Med. 180(2): 176-180. DOI: 10.- 1164/rccm.200901-00460.

WHO (2014). Global Nutrition Targets 2025: Low birth weight policy brief.

WHO (2016). World health statistics 2016: monitoring health for the SDGs, sustainable development goals. In: Implications of the SDGs for health monitoring-a challenge and an opportunity for all countries.

Zeleke BM, Zelalem M, Mohammed N (2012). Incidence and correlates of low birth weight at a referral hospital in Northwest Ethiopia. Pan Afr Med J. 12: 4 .

Zhang G, Bacelis J, Lengyel C, Teramo K, Hallman M, Helgeland Ø, Johansson $\mathrm{S}$, et al. (2015). Assessing the Causal Relationship of Maternal Height on Birth Size and Gestational Age at Birth: A Mendelian Randomization Analysis. PLoS Med. 12(8): e1001865. DOI: 10.1371/journal.pmed.1001865. 